\title{
Planting Geometry Effects on the Growth and Yield of Dryland Cotton
}

\author{
R. L. Baumhardt' ${ }^{1}$ R. C. Schwartz ${ }^{1}$, G. W. Marek $^{1}$, J. M. Bell ${ }^{2}$ \\ ${ }^{1}$ Soil and Water Management Research, Conservation and Production Research Laboratory, USDA-ARS, Bushland, TX, USA \\ ${ }^{2}$ Agronomy, Texas A \& M AgriLife Research and Extension, Amarillo, TX, USA \\ Email: R.Louis.Baumhardt@ars.usda.gov
}

How to cite this paper: Baumhardt, R.L., Schwartz, R.C., Marek, G.W. and Bell, J.M. (2018) Planting Geometry Effects on the Growth and Yield of Dryland Cotton. Agricultural Sciences, 9, 99-116. https://doi.org/10.4236/as.2018.91008

Received: December 4, 2017

Accepted: January 22, 2018

Published: January 25, 2018

Copyright ( $) 2018$ by authors and Scientific Research Publishing Inc. This work is licensed under the Creative Commons Attribution-NonCommercial International License (CC BY-NC 4.0). http://creativecommons.org/licenses/by-nc/4.0/ cc) (†) (8) Open Access

\begin{abstract}
The declining Ogallala Aquifer beneath the Southern High Plains may necessitate dryland crop production and cotton (Gossypium hirsutum L.) is a well-adapted and potentially profitable alternative crop. The limited growing season duration of the Texas Panhandle and southwestern Kansas, however, imposes significant production risk due to incomplete boll maturation. Emphasizing earlier boll production that is usually confined to sites on lower fruiting branches may reduce risk, but offsetting high planting densities are needed to maintain desirable lint yield. Our objectives were to quantify planting: 1) row width and 2) in-row spacing effects on growth, yield, and fiber quality of dryland cotton. Field tests of row widths from 0.25 to $0.76 \mathrm{~m}$ and plant densities with in-row spacing ranging from 0.075 to $0.15 \mathrm{~m}$ were conducted from 1999 to 2005 on a nearly level Pullman clay loam (fine, mixed, superactive, thermic Torrertic Paleustoll) managed in a wheat (Triticum aestivum L.), cotton, fallow (W-Ctn-F) rotation. To expand the basis of comparison, cotton growth and yields were simulated using GOSSYM and long-term (1958-2000) weather records from Bushland, TX, as input for all combinations of 0.38 or $0.76 \mathrm{~m}$ row widths and plant spacing of $0.075,0.10$ and 0.15 $\mathrm{m}$. Experimental and computer simulated plant height and harvested boll number increased significantly with increased row spacing and, occasionally, in-row plant spacing. Modeled lint yield for $0.38 \mathrm{~m}$ rows decreased by approximately $50 \%$ compared with the $582 \mathrm{~kg} \cdot \mathrm{ha}^{-1}$ yield for conventional row spacing, which was practically duplicated by field observations in 2001 and 2004. Measured fiber quality occasionally improved with conventional row spacing over ultra-narrow rows, but was unaffected by plant spacing. Because narrow rows and frequent plant spacing did not improve lint yield or fiber quality of dryland cotton, we do not recommend this strategy to overcome a thermally limited growing season.
\end{abstract}




\section{Keywords}

Dryland Crop Production, Thermally Limited Growing Season, Ultra-Narrow Row Spacing

\section{Introduction}

Mean annual precipitation for much of the semiarid Southern Great Plains region meets from $41 \%$ to $61 \%$ of the potential evapotranspiration (ET) [1] and often requires irrigation to realize full potential crop yield. This irrigation water is pumped from the underlying Ogallala or High Plains Aquifer at a rate generally exceeding recharge [2]. As a result, the Ogallala Aquifer is declining at a rate averaging a spatially weighted $-4.8 \mathrm{~m}$ since pre-development with water level changes of $-8.0 \mathrm{~m}$ for Kansas and $-12.5 \mathrm{~m}$ for Texas [3]. Dryland cropping systems exemplify a sustainable alternative to irrigated production supported from the Ogallala Aquifer, but dryland profitability must be increased to preserve southern Great Plains agriculture. Cotton may be a profitable alternative crop that performs well under dryland conditions.

The growing season conditions of western Kansas and the northern half of the Texas High Plains are arguably too limited in duration to provide adequate energy for optimum cotton yield. That is, if cotton blooming after 20 August has less than a 50\% chance of maturing near Lubbock, Texas [4] then this date likely advances when moving north to Kansas. Potential incomplete boll and lint development that requires 472 growing degree days (GDD15.5) after bloom may resemble premature harvest-aid defoliation for terminated photosynthesis and depressed yield [5]. Although the possibility of crop failure during any given year was significant, [6] used the mean long term energy for this region to estimate cotton yields from up to six open and the nearly, 85\%, mature bolls that ranged from $<500 \mathrm{~kg} \cdot \mathrm{ha}^{-1}$ to $1000 \mathrm{~kg} \cdot \mathrm{ha}^{-1}$. Cotton production that emphasizes early set bolls may address growing season concerns of risk-averse producers, but necessarily must increase population to maintain yield potential.

The production strategy of increasing plant population through more frequent row or plant spacing generally advances soil water extracted for plant use and often expands production risk in semiarid regions [7]. Recommended dryland plant spacing for a fixed row width in the Texas High Plains can range from 75 to $150 \mathrm{~mm}$ depending on the prevailing precipitation conditions [8]. Alternatively, cotton yield was not influenced by population in fixed row widths when water stress was minimized by irrigation [9] [10]. Researchers in central Texas planted cotton in 0.19 and $0.38 \mathrm{~m}$ rows to increase population for improved earliness and yield increases of $37 \%$ to $21 \%$ compared with conventional, $0.76 \mathrm{~m}$, row spacing with no difference in plant height [11]. In west Tennessee, [12] also observed time to crop maturity for narrow, $0.38 \mathrm{~m}$, row cotton was less than for 
the $0.76 \mathrm{~m}$ row spacing with lint yields that were numerically if not significantly greater. Narrow and ultra-narrow row spacing facilitates a higher planting density that can increase yield if crop water demand is met, but often reduces plant height and yield during drier growing conditions [13] [14]. Except for one year where August to mid-September precipitation of $1 \mathrm{~mm}$ per day imposed drought stress on cotton during much of the fruit set, UNR or ultra-narrow, $0.19 \mathrm{~m}$, row spacing yield exceeded conventional row spacing for an overall three year average increase of $12 \%$ [15]. Other contrasting studies in southern Alabama reporting equivalent or marginally different lint yields observed for $0.38 \mathrm{~m}$ and $1.02 \mathrm{~m}$ rows that received above average or at least normal growing season rain recommended further economic evaluation of narrow row spacing strategy for profitability [16]. In lieu of adequate precipitation, cotton performance may favor conventional row spacing compared with either narrow or ultra-narrow, $0.19 \mathrm{~m}$ or $0.38 \mathrm{~m}$, row spacing.

We hypothesize that dryland cotton may mature $2-4$ bolls per plant despite the often short growing season in southwestern Kansas and the northern Texas Panhandle. We found no report where narrow rows were used to accommodate higher plant populations that permitted dryland cotton to produce an economical yield on stored soil water and available precipitation. Our objectives were to quantify planting 1) row width and 2) in-row spacing effects on growth, yield, and fiber quality of dryland cotton using both field experiments and crop growth simulation.

\section{Materials and Methods}

\subsection{Field Experiment}

Using crop growth simulation and a field experiment conducted from 1999 to 2005 at the USDA-ARS Conservation and Production Research Laboratory, Bushland, TX $\left(35^{\circ} 11^{\prime} \mathrm{N}, 102^{\circ} 5^{\prime} \mathrm{W}\right.$; and $\left.1170 \mathrm{~m} \mathrm{MSL}\right)$ we evaluated row spacing and plant population effects on growth and yield of dryland cotton. A dryland wheat-cotton-fallow (W-Ctn-F) rotation that produces two crops in three years using, in part, precipitation stored during intervening 10-month idle/fallow periods was established on a $510 \mathrm{~m}$ long by $110 \mathrm{~m}$ wide nearly level Pullman clay loam [17]. We subdivided the 5.6 ha site into three $36 \mathrm{~m}$ wide strips that were sequentially assigned to wheat, cotton, and fallow after cotton so that each rotation phase appeared every year.

The wheat phase of our rotation began in September - October when soil water permitted establishment. The uniformly managed wheat (cv. TAM-110 Foundation Seed, College Station, TX) was planted using a high-clearance hoe opener grain drill at $\sim 50 \mathrm{~kg} \cdot \mathrm{ha}^{-1}$ sowing rate to achieve 200 plants $\cdot \mathrm{m}^{-2}$ in rows $0.3 \mathrm{~m}$ apart. No soil active herbicides were used to control growing season weeds because of potential residual effects on sensitive rotation crops, but spring broadleaf weeds were controlled as necessary by applying $0.56 \mathrm{~kg}$ a.i. $\mathrm{ha}^{-1} 2,4-\mathrm{D}$ 
[(2, 4-dichlorophenoxy) acetic acid] before 1 May. This first phase of the $\mathrm{W}-\mathrm{Ctn}-\mathrm{F}$ rotation was typically machine harvested in July and then fallowed 10 -months through winter until mid-May of the rotation second year. Weed control during the fallow after wheat and subsequent cotton crops was exclusively by on demand ( 3 - 4 operations) SM tillage to a $0.10-\mathrm{m}$ depth using a 4.6-m-wide Richardson sweep-plow (Sunflower Mfg. Co., Inc., Beloit, KS). Annual mineralization and atmospheric deposition of $\mathrm{N}$ totals $\sim 47 \mathrm{~kg} \cdot \mathrm{ha}^{-1}$ for the Pullman soil [18]; therefore, no fertilizer $\mathrm{N}$ was needed to achieve the expected dryland yields for wheat [19] and cotton lint [20]. We applied no P or K fertilizer because the Pullman clay mineralogy supplies sufficient $\mathrm{K}$ to meet crop demand [21] and dryland crop response to broadcast applied P fertilizer has been limited [22] [23].

The cotton rotation-phase began after soil water and temperature suited seed germination with planting on May 16 - 24 except for a 2003 drought delay until 17 June. From 1999 until 2001 PM-183 (Cargill Research, Plainview, TX) was planted using a John Deer 750 no-till drill (Deere \& Co., Moline, IL) in four $170-\mathrm{m}$ long and 9-m wide main plots of randomly assigned $0.50 \mathrm{~m}$ and $0.76 \mathrm{~m}$ row width main plots replicated three times. Each main plot was subdivided into three $56-\mathrm{m}$ long split plots with random $0.15,0.10$, and $0.075 \mathrm{~m}$ in-row seed spacing treatments. The resulting net seeding rates were approximately 13.1, 19.7, and 26.2 seeds $\cdot \mathrm{m}^{-2}$ for narrow, $0.5 \mathrm{~m}$, rows or $8.7,13.1$, and 17.5 seeds $\cdot \mathrm{m}^{-2}$ for conventional, $0.76 \mathrm{~m}$, row spacing. Growing season weeds were controlled with a pre-plant application of trifluralin [2, 6-dinitro-N, N-dipropyl-4-(trifluoromethyl) benzenamine] at $0.7 \mathrm{~kg}$ a.i. ha ${ }^{-1}$. After 2001, we changed to a glyphosate [N-(phosphonomethyl) glycine] tolerant cotton cultivar, PM-2145RR, for improved seasonal weed control with on demand applications of $0.56 \mathrm{~kg}$ a.i. ha $^{-1}$ glyphosate.

Beginning 2002, the higher population $0.076 \mathrm{~m}$ in-row spacing was discontinued and a $0.25 \mathrm{~m}$ ultra-narrow row width added. Cotton was then seeded using a Monosem NG Plus vacuum planter (Edwardsville, KS) in $170 \mathrm{~m} \times 9 \mathrm{~m}$ main plots of four randomly assigned $0.15 \mathrm{~m}$ and $0.10 \mathrm{~m}$ in-row spacing main plots replicated three times. Each of these main plots were subdivided into three equal split plots with random $0.25,0.5$, and $0.76 \mathrm{~m}$ row widths. Net seeding rates per $\mathrm{m}^{2}$ for the 0.15 and $0.10 \mathrm{~m}$ in-row spacing approximated 26.2 and 39.4 in the ultra-narrow rows, 13.1 and 19.7 for the $0.50 \mathrm{~m}$ narrow rows, and 8.7 and 13.1 for $0.76 \mathrm{~m}$ rows. Cotton was harvested at maturity in November followed by a $\sim 10$-month fallow phase before the rotation was repeated with wheat planting in late September or early October).

\subsection{Field Measurements and Analyses}

Final plant population, boll number, and lint yield were determined at maturity from $13.95 \mathrm{~m}^{2}$ hand samples harvested from $9.1 \mathrm{~m}$ long rows centered in each plot. Bur cotton samples were ginned at the Texas A \& M AgriLife Research and 
Extension Center at Lubbock and routine fiber quality parameters were quantified with a high volume instrument by the Fiber and Biopolymer Research Institute in Lubbock. Seasonal cotton water use was determined from the sum of the official location precipitation ( $0.75 \mathrm{~km}$ away) and the calculated difference in soil water at planting and harvest, assuming no contribution by upward flux from the $\sim 100 \mathrm{~m}$ deep water table and likely negligible runon, runoff, or drainage during the summer growing season [17]. Soil water measurements were based on duplicate gravimetric soil cores taken to a $1.8 \mathrm{~m}$ depth and sampled in $0.3 \mathrm{~m}$ increments that were converted to volumetric soil water using previously measured soil density as described by [24].

All possible combinations of in-row plant spacing and combination cultivar and row widths were replicated three times as $170 \mathrm{~m}$ long blocks to produce 36 (9 by $56 \mathrm{~m}$ ) plots. We compared measured soil water and cotton growth and yield factors in response to cultivar, intra and inter-row spacing fixed effects according to a randomized complete block split plot design [25] using SAS mixed linear model ANOVA procedures [26]. Random effects were block and block $\times$ (row spacing) until 2002 when random effects were block and block $\times$ (plant spacing). We analyzed all dependent parameter responses to inter-row and intra-row spacing effects within years because of annually variable growing season conditions including air temperatures, and precipitation distribution and amount.

\subsection{Model Uncertainty and Crop Simulations}

The accuracy of the computer crop growth simulation model GOSSYM ver. 4 [27] [28] to simulate plant responses under variable growing conditions is critical in evaluating the effects of cultural practices on cotton growth and yield. Although GOSSYM was previously validated for the Southern High Plains by [29], yield of dryland cotton grown in $0.76 \mathrm{~m}$ rows at a 13 plants $\mathrm{m}^{-2}$ population during four growing seasons from 1995 to 2000 at Bushland, TX were compared to modeled yields based on the recorded conditions. Problematic in-field crop establishment due to limited soil water delayed actual planting that, consequently, depressed dryland cotton growth during already short growing season. Eliminating any delayed planting bias reduced the number of available comparisons. Nevertheless, a paired t-test indicated model projected mean yields of 220 $\mathrm{kg} \cdot \mathrm{ha}^{-1}$ did not differ significantly from the corresponding $15 \%$ larger measured yields that averaged $253 \mathrm{~kg} \cdot \mathrm{ha}^{-1}$. We regressed measured lint yields $(n=8)$ on the corresponding model calculated values (Figure 1 ) to produce a highly correlated, $r=0.92$, relationship with a slope of 0.84 and RMSE of $41.2 \mathrm{~kg} \cdot \mathrm{ha}^{-1}$. That is, observed yields exceeded the modeled estimates calculated for the recorded weather conditions with a difference of $+15 \%$ at $200 \mathrm{~kg} \cdot \mathrm{ha}^{-1}$, declining to practically the same for measured and modeled yields approaching $400 \mathrm{~kg} \cdot \mathrm{ha}^{-1}$. Model projected yields shifted to a slight, $2 \%$ to $5 \%$, overestimation when observed yield approached 500 to $600 \mathrm{~kg} \cdot \mathrm{ha}^{-1}$. These results, although not 1:1, suggest that 


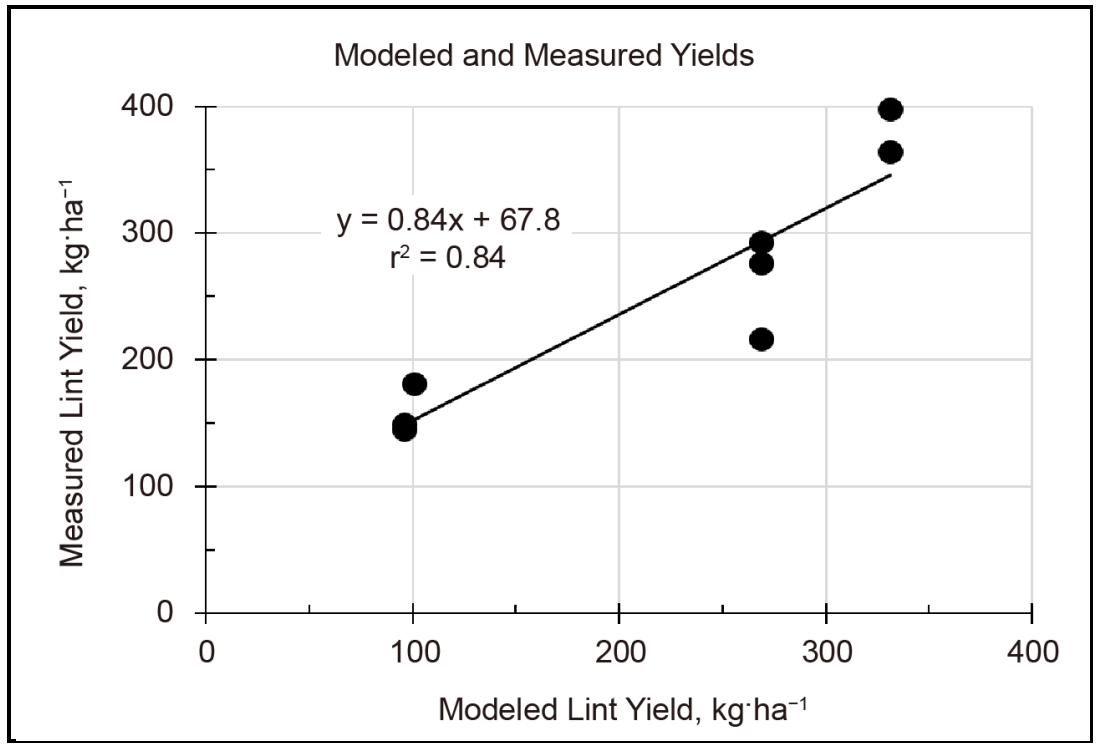

Figure 1. Cotton lint yields simulated using GOSSYM for known planting conditions and recorded precipitation at Bushland, TX regressed on the corresponding experimental yields measured during 1995 and 1998 to 2000.

modeled yields of dryland cotton that ranged from 300 to $500 \mathrm{~kg} \cdot \mathrm{ha}^{-1}$ would objectively represent actual crop performance.

We, therefore, used the computer crop growth simulation model GOSSYM with long-term (1958-2000) weather records at Bushland, TX to expand the basis for comparing row width and plant spacing effects on dryland cotton despite annual climatic variability. All possible combinations of narrow, $0.38 \mathrm{~m}$, or conventional, $0.76 \mathrm{~m}$, row spacing and intra-row plant spacing of 75,100, and 150 $\mathrm{mm}$ for populations, in plants. $\mathrm{m}^{-2}$, of $8.8,13.1$, and 17.5 (conventional) or 17.5, 26.3, and 35.1 (narrow) were simulated. For these conditions, we calculated the growth and yield of a stripper type cotton cultivar having an indeterminate growth habit similar to All-Tex Atlas (Levelland, TX) as described by the supplied variety file ST1 [29]. Weather records included the model required daily solar irradiance $\left(\mathrm{MJ} \cdot \mathrm{m}^{-2}\right)$, maximum and minimum air temperature $\left({ }^{\circ} \mathrm{C}\right)$, precipitation $(\mathrm{mm})$, and wind run $(\mathrm{km})$ input. The soil profile was a $1.8-\mathrm{m}$ deep Pullman clay loam described in two horizons $(0.0-0.3$ and $0.3-1.8 \mathrm{~m})$ with soil bulk density, texture, and hydrologic properties based on field measurements [30] or the values supplied with the model for a Pullman soil at Lubbock, TX. The initial soil profile water content for all simulations was uniformly fixed at $100 \%$ of field capacity to optimize crop establishment and potential lint yield. No fertilizer $\mathrm{N}$ was applied because, as previously noted, annual atmospheric deposition and mineralization for a Pullman soil totaling $\sim 47 \mathrm{~kg} \mathrm{~N} \mathrm{ha}^{-1}$ [18] is sufficient to achieve $\sim 500 \mathrm{~kg} \cdot \mathrm{ha}^{-1}$ lint yields [20] that might be expected for dryland cotton at Bushland. The effects of other nutrients on cotton growth are not simulated by GOSSYM and were not specified [31]. Simulations began on day of year (DOY) 131 or $2 \mathrm{wk}$ before the target DOY 145 emergence date that 
follows $10 \mathrm{~d}$ after the recommended 15 May planting date for Bushland. Simulations continued until physiological maturity (100\% open bolls) or a killing freeze, when lint yield and estimated water use or growing season ET were determined.

Using SAS mixed model ANOVA procedures [26], we compared row spacing and plant spacing fixed effects on cotton growth and yield according to a factorial arrangement of a completely randomized design replicated by years as random effects. Those plant growth and yield factors were the simulated harvest height and node number, LAI at first open boll, days between bloom and cutout, yield and boll numbers on both a plant and spatial basis.

\section{Results and Discussion}

Dryland cropping systems depend exclusively on precipitation for crop establishment in lieu of any pre-plant irrigation to adjust seed zone soil water. We show cumulative mean monthly May through September cotton growing season precipitation for the study years 1999-2004 compared with the long-term 1939-2013 average (Figure 2(a)) and the corresponding cumulative growing season thermal energy (Figure 2(b)). Long-term growing season precipitation at Bushland averages about $60 \mathrm{~mm}$ for May, increasing to $130 \mathrm{~mm}$ by 30 June and is typically adequate for seedling germination and establishment. In our experiment, cumulative precipitation for the 15 May to 30 June crop establishment period in 2002 of $26 \mathrm{~mm}$ did not permit timely establishment of cotton. Although 2005 cotton emergence was timely, a 12 June hailstorm completely defoliated the plants and severed practically all terminal buds; thus, destroying the crop. That storm was sufficiently late in relation to the potential growing season energy to preclude replanting, forfeiting the subsequent growing season precipitation that was $95 \%$ of the $310 \mathrm{~mm}$ average (data not shown).

Of the five growing seasons that produced cotton, monthly precipitation during 1999 exceeded the long-term average by 50 to $>100 \mathrm{~mm}$ with a seasonal total of $410 \mathrm{~mm}$ that exceeded more than $\sim 80 \%$ of the 75 years of record (Figure 2 (a)). Cumulative precipitation during the 2000, 2001, and 2003 approached the $130 \mathrm{~mm}$ seasonal average by June, but generally fell below the long-term average during the rest of the growing season, ranging from $140 \mathrm{~mm}$ in 2000 up to 210 $\mathrm{mm}$ in 2003 or drier than $96 \%$ to $83 \%$ of the 75 year record. Only the 2004 growing season approximated the seasonal mean cumulative precipitation of 310 mm, although July and August values like all test years other than 1999 were less than long-term mean precipitation. These data suggest that the expected dryland cotton yields will likely reflect water stress as a result of the below average precipitation.

The long-term calculated $15.5^{\circ} \mathrm{C}$ base thermal energy averages about 1000 GDD15.5 at Bushland between 15 May and the end of September (Figure 2(b)), which is capable of supporting cotton yields from $0.50-1.0 \mathrm{Mg} \mathrm{ha}^{-1}$ [6]. During our study, four of the five successful growing seasons exceeded long-term 

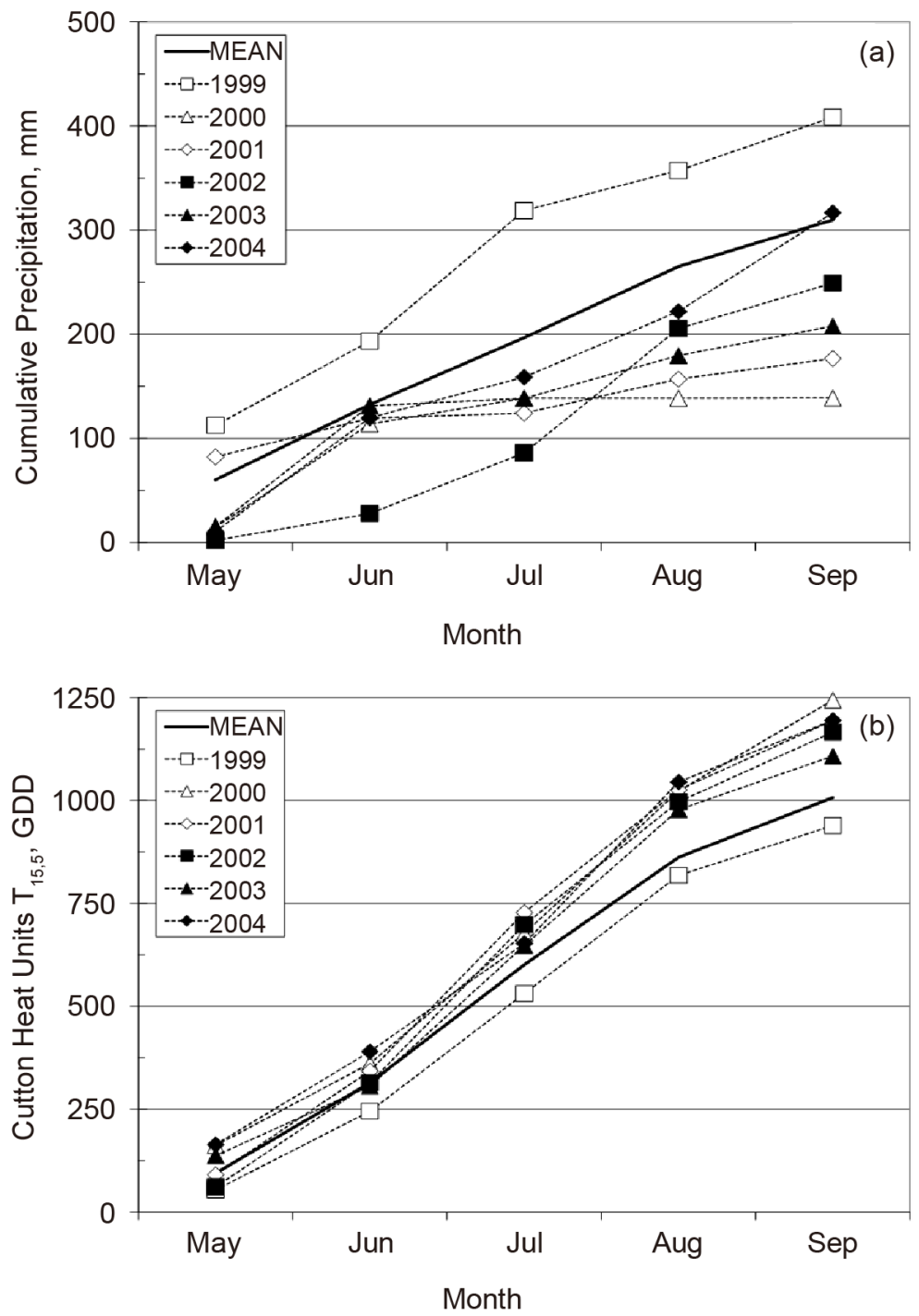

Figure 2. The May through September growing season cumulative mean monthly precipitation (a) and the corresponding base $15.5^{\circ} \mathrm{C}$ thermal energy (b) at Bushland, TX for the study years 1999-2004 compared with the long-term, 1939-2013, average.

September mean cotton thermal energy, ranging from a low of 1110 GDD15.5 in 2003 to a 1240 GDD15.5 maximum in 2000. During those four years, the mean monthly cumulative growing season energy exceeded the long-term average by $10 \%$ to $20 \%$ during most months but certainly after June (Figure 2 (b)). The exceptional year, 1999, that featured above average precipitation realized cumulative seasonal heat unit energy of 940 GDD15.5 and consistently remained $10 \%$ to $20 \%$ less than the long-term average during the entire growing season (Figure 2(b)). These data indicate that precipitation and not growing season energy would likely limit cotton lint production during our study.

\subsection{Growth Factors}

Plant height measured at harvest, shown in Table 1, reflected the growing 
Table 1. Mean plant height and boll number at harvest for each year in response to row width (RW), m, and plant spacing (PS), $\mathrm{m}$, with the corresponding ANOVA significance levels.

\begin{tabular}{|c|c|c|c|c|c|c|c|c|c|c|}
\hline \multirow{2}{*}{ Effect } & 1999 & 2000 & 2001 & 2003 & 2004 & 1999 & 2000 & 2001 & 2003 & 2004 \\
\hline & \multicolumn{5}{|c|}{$\longrightarrow$ Plant Height, $\mathrm{m}^{\mathrm{a}} \longrightarrow$} & \multicolumn{5}{|c|}{ Bolls per Plant ${ }^{\mathrm{a}} \longrightarrow$} \\
\hline RW, m 0.25 & -- & -- & -- & $0.46 b$ & $0.48 \mathrm{c}$ & -- & -- & -- & $1.8 \mathrm{~b}$ & $1.7 \mathrm{~b}$ \\
\hline 0.50 & $0.50 \mathrm{~b}$ & $0.47 \mathrm{a}$ & $0.37 \mathrm{~b}$ & $0.61 \mathrm{a}$ & $0.67 \mathrm{~b}$ & $2.8 \mathrm{a}$ & $1.6 \mathrm{a}$ & $2.4 \mathrm{a}$ & $2.4 \mathrm{~b}$ & $3.1 \mathrm{a}$ \\
\hline 0.76 & $0.60 \mathrm{a}$ & $0.49 \mathrm{a}$ & $0.44 \mathrm{a}$ & $0.63 \mathrm{a}$ & $0.78 \mathrm{a}$ & $2.7 \mathrm{a}$ & $1.9 \mathrm{a}$ & $2.5 \mathrm{a}$ & $4.6 \mathrm{a}$ & $3.6 \mathrm{a}$ \\
\hline PS, m 0.15 & $0.59 \mathrm{a}$ & $0.50 \mathrm{a}$ & $0.43 \mathrm{a}$ & $0.60 \mathrm{a}$ & $0.63 \mathrm{a}$ & $3.0 \mathrm{a}$ & $1.6 \mathrm{a}$ & $2.8 \mathrm{a}$ & $3.3 \mathrm{a}$ & $2.9 \mathrm{a}$ \\
\hline 0.10 & $0.53 b$ & $0.48 \mathrm{a}$ & $0.40 \mathrm{~b}$ & $0.53 \mathrm{a}$ & $0.66 \mathrm{a}$ & $2.6 \mathrm{ab}$ & $1.5 \mathrm{a}$ & $2.4 \mathrm{~b}$ & $2.6 \mathrm{a}$ & $2.7 \mathrm{a}$ \\
\hline 0.075 & $0.53 b$ & $0.46 \mathrm{~b}$ & $0.39 \mathrm{c}$ & -- & -- & $2.4 \mathrm{~b}$ & $2.2 \mathrm{a}$ & $2.0 \mathrm{c}$ & -- & -- \\
\hline \multicolumn{11}{|l|}{$\mathrm{RW} \times \mathrm{PS}$} \\
\hline $0.25 \times 0.150$ & -- & -- & -- & $0.51 \mathrm{ab}$ & $0.54 \mathrm{c}$ & -- & -- & -- & $1.7 \mathrm{~b}$ & $1.4 \mathrm{c}$ \\
\hline $0.25 \times 0.100$ & -- & -- & -- & $0.41 \mathrm{~b}$ & $0.42 \mathrm{~d}$ & -- & -- & -- & $1.9 \mathrm{~b}$ & $2.1 \mathrm{bc}$ \\
\hline $0.25 \times 0.075$ & -- & -- & -- & -- & -- & -- & -- & -- & -- & -- \\
\hline $0.50 \times 0.150$ & $0.51 b c$ & $0.49 \mathrm{ab}$ & $0.39 c$ & $0.60 \mathrm{ab}$ & $0.61 \mathrm{c}$ & $3.1 \mathrm{a}$ & $1.9 \mathrm{a}$ & $2.8 \mathrm{a}$ & $2.7 \mathrm{ab}$ & $3.6 \mathrm{a}$ \\
\hline $0.50 \times 0.100$ & $0.48 \mathrm{c}$ & $0.48 \mathrm{ab}$ & $0.37 \mathrm{c}$ & $0.62 \mathrm{a}$ & $0.72 b$ & $2.9 \mathrm{ab}$ & $1.5 \mathrm{a}$ & $2.4 \mathrm{ab}$ & $2.2 \mathrm{ab}$ & $2.5 \mathrm{~b}$ \\
\hline $0.50 \times 0.075$ & $0.49 \mathrm{c}$ & $0.46 \mathrm{~b}$ & $0.35 \mathrm{c}$ & -- & -- & $2.3 \mathrm{~b}$ & $1.5 \mathrm{a}$ & $1.9 \mathrm{~b}$ & -- & -- \\
\hline $0.76 \times 0.150$ & $0.66 a$ & $0.50 \mathrm{a}$ & $0.47 \mathrm{a}$ & $0.70 \mathrm{a}$ & $0.73 b$ & $3.0 \mathrm{a}$ & $1.4 \mathrm{a}$ & $2.9 \mathrm{a}$ & $5.3 \mathrm{a}$ & $3.7 \mathrm{a}$ \\
\hline $0.76 \times 0.100$ & $0.57 \mathrm{~b}$ & $0.49 \mathrm{ab}$ & $0.43 \mathrm{~b}$ & $0.55 \mathrm{ab}$ & $0.83 a$ & $2.4 \mathrm{~b}$ & $1.5 \mathrm{a}$ & $2.5 \mathrm{ab}$ & $3.8 \mathrm{ab}$ & $3.4 \mathrm{a}$ \\
\hline $0.76 \times 0.075$ & $0.57 \mathrm{~b}$ & $0.47 \mathrm{~b}$ & $0.42 \mathrm{~b}$ & -- & -- & $2.5 \mathrm{ab}$ & $2.9 \mathrm{a}$ & $2.0 \mathrm{~b}$ & -- & -- \\
\hline \multicolumn{11}{|l|}{ Significance } \\
\hline RW & 0.0163 & 0.1946 & 0.0037 & 0.0052 & $<0.0001$ & 0.6391 & 0.4663 & 0.4747 & 0.0019 & $<0.0001$ \\
\hline PS & 0.0110 & 0.0024 & $<0.0001$ & 0.1364 & 0.1296 & 0.0493 & 0.2409 & 0.0006 & 0.4840 & 0.3215 \\
\hline $\mathrm{RW} \times \mathrm{PS}$ & 0.0906 & 0.8599 & 0.3613 & 0.1560 & $<0.0001$ & 0.3339 & 0.1236 & 0.9471 & 0.3255 & 0.0089 \\
\hline
\end{tabular}

a. Means of effects for the same year followed by the same letter are not significantly different, $\mathrm{P}<0.05$, according to the Tukey significant difference test.

season conditions that may have been more nearly ideal in 2004 with precipitation that approached the long-term average and above average thermal energy. Despite receiving above average precipitation in 1999, plant height was less than during 2004 possibly because of below average thermal energy. Not surprisingly, the overall shortest plants grew during the drier years of 2000 and 2001 probably as a result of water deficit stress. Although decreasing the row spacing presents a way to increase plant population without using a more frequent plant spacing, our measured plant height for the $0.76 \mathrm{~m}$ row width was significantly greater than for the $0.25 \mathrm{~m}$ or $0.50 \mathrm{~m}$ row spacing in contrast to findings by [11]. Model calculated plant height averaged over 42 growing seasons for the narrow, $0.38 \mathrm{~m}$, row spacing was about $70 \%$ of the significantly larger $0.50 \mathrm{~m}$ plant height for the $0.76 \mathrm{~m}$ row spacing (Table 2). Increased intra-row plant spacing that reduces population for a fixed row width has the potential to reduce competition for available water and resulted in often significantly larger plant heights for the 0.15 
Table 2. Model calculated mean plant height and boll number, leaf area index (LAI) at first open boll, days from bloom to cutout, and lint yield as affected by row width (RW), $\mathrm{m}$, and in-row plant spacing (PS), $\mathrm{m}$, with the corresponding ANOVA significance levels.

\begin{tabular}{|c|c|c|c|c|c|}
\hline Effect & Height $\underline{m}^{a}$ & Bolls.plant $^{-1}$ & 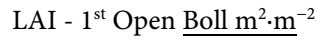 & Bloom to Cutout, Days & ${\text { Yield } \mathrm{kg} \cdot \mathrm{ha}^{-1}}^{-1}$ \\
\hline $\mathrm{RW}, \mathrm{m} 0.38$ & $0.34 \mathrm{~b}$ & $1.8 \mathrm{~b}$ & $1.70 \mathrm{~b}$ & $8.6 \mathrm{~b}$ & $278.3 \mathrm{~b}$ \\
\hline 0.76 & $0.50 \mathrm{a}$ & $7.0 \mathrm{a}$ & $2.18 \mathrm{a}$ & $23.6 \mathrm{a}$ & $582.0 \mathrm{a}$ \\
\hline PS, $\mathrm{m} 0.15$ & $0.43 \mathrm{a}$ & $6.0 \mathrm{a}$ & $1.99 \mathrm{a}$ & $17.8 \mathrm{a}$ & $441.5 \mathrm{a}$ \\
\hline 0.10 & $0.42 \mathrm{a}$ & $4.1 \mathrm{~b}$ & $1.95 \mathrm{a}$ & $15.8 \mathrm{~b}$ & $427.8 \mathrm{a}$ \\
\hline 0.075 & $0.42 \mathrm{a}$ & $3.1 \mathrm{c}$ & $1.88 \mathrm{a}$ & $14.6 \mathrm{~b}$ & $421.2 \mathrm{a}$ \\
\hline \multicolumn{6}{|l|}{$\mathrm{RW} \times \mathrm{PS}$} \\
\hline $0.38 \times 0.150$ & $0.33 \mathrm{~d}$ & $2.2 \mathrm{~d}$ & $1.63 \mathrm{c}$ & $7.1 \mathrm{~d}$ & $290.0 \mathrm{~b}$ \\
\hline $0.38 \times 0.100$ & $0.35 \mathrm{c}$ & $1.7 \mathrm{de}$ & $1.73 \mathrm{c}$ & $8.7 \mathrm{~d}$ & $273.8 \mathrm{~b}$ \\
\hline $0.38 \times 0.075$ & $0.35 \mathrm{c}$ & $1.4 \mathrm{e}$ & $1.75 \mathrm{c}$ & $10.0 \mathrm{~d}$ & $271.0 \mathrm{~b}$ \\
\hline $0.76 \times 0.150$ & $0.52 \mathrm{a}$ & $9.8 \mathrm{a}$ & $2.35 \mathrm{a}$ & $28.5 \mathrm{a}$ & $593.0 \mathrm{a}$ \\
\hline $0.76 \times 0.100$ & $0.49 \mathrm{~b}$ & $6.5 \mathrm{~b}$ & $2.17 \mathrm{ab}$ & $22.9 \mathrm{~b}$ & $581.7 \mathrm{a}$ \\
\hline $0.76 \times 0.075$ & $0.48 \mathrm{~b}$ & $4.7 \mathrm{c}$ & $2.00 \mathrm{~b}$ & $19.3 \mathrm{c}$ & $571.4 \mathrm{a}$ \\
\hline \multicolumn{6}{|l|}{ Significance } \\
\hline RW & $<0.0001$ & $<0.0001$ & $<0.0001$ & $<0.0001$ & $<0.0001$ \\
\hline PS & 0.0577 & $<0.0001$ & 0.1537 & 0.0012 & 0.1476 \\
\hline $\mathrm{RW} \times \mathrm{PS}$ & $<0.0001$ & $<0.0001$ & $<0.0001$ & $<0.0005$ & 0.9365 \\
\hline
\end{tabular}

a. Means of effects for the same year followed by the same letter are not significantly different, $\mathrm{P}<0.05$, according to the Tukey significant difference test.

$\mathrm{m}$ plant spacing compared with the $0.075 \mathrm{~m}$ and, occasionally, $0.10 \mathrm{~m}$ spacing (Table 1). The modeled effects of in-row plant spacing on the 42 year average cotton plant height shown in Table 2, by contrast, did not vary significantly with plant spacing. Our data show that cotton plant height was generally depressed by narrow row spacing as previously reported [12] [14] [32], but not by decreased plant spacing.

The observed boll number at harvest shown in Table 1 did not differ between row widths of $0.76 \mathrm{~m}$ and $0.50 \mathrm{~m}$ except for a $50 \%$ decrease during 2003. Cotton grown in the ultra-narrow, $0.25 \mathrm{~m}$, row width consistently featured fewer bolls at harvest than for the $0.5 \mathrm{~m}$ row spacing and significantly fewer than with the conventional $0.76 \mathrm{~m}$ row spacing. The mean harvested boll number differed in favor of the $0.15 \mathrm{~m}$ plant spacing over the $0.075 \mathrm{~m}$ spacing during only 2 of the growing seasons possibly due to favorable above average precipitation in May. As was observed for model calculated plant height, the corresponding mean boll number for the conventional $0.76 \mathrm{~m}$ rows were significantly greater than for the $0.38 \mathrm{~m}$ row spacing (Table 2 ). Cotton boll number also increased significantly as plant spacing increased, suggesting that fewer plants in close proximity would tend to reduce water deficit stress and increase fruiting.

Leaf area index (LAI) at first open boll and the time elapsed between bloom 
and cutout reflect growing conditions promoting plant vigor. The model calculated LAI for the $0.38 \mathrm{~m}$, narrow, row spacing was approximately $80 \%$ of that calculated for the overall larger plants for the $0.76 \mathrm{~m}$, conventional, row spacing, but did not differ with plant spacing (Table 2). The modeled number of days from emergence to bloom did not vary with row or plant spacing (data not shown), but $0.38 \mathrm{~m}$ rows advanced cutout and reduced the time elapsed between bloom and cutout to about 9 days for narrow rows and $>23$ days for conventional rows. The period from bloom to cutout also decreased significantly from 17.8 $\mathrm{d}$ to fewer than $16 \mathrm{~d}$ as plant spacing was reduced from $0.15 \mathrm{~m}$ to $<0.10 \mathrm{~m}$, suggesting the lower plant population decreased water deficit stress and expanded the bloom to cutout period. This expanded period between bloom and cutout translates to greater fruiting opportunities and potential yield.

\subsection{Lint Yield and Fiber Quality}

Our measured dryland lint yield (Table 3) reflected the cumulative rain and its growing season distribution and soil water use. Peak lint yield averaged 406

Table 3. Mean lint yield, $\mathrm{kg} \cdot \mathrm{ha}^{-1}$, for each harvested study year in response to row width and plant spacing, $\mathrm{m}$, treatments with the corresponding ANOVA significance levels.

\begin{tabular}{|c|c|c|c|c|c|}
\hline \multirow{2}{*}{ Effect } & 1999 & 2000 & 2001 & 2003 & \multirow[t]{2}{*}{2004} \\
\hline & & \multicolumn{3}{|c|}{ - Lint Yield, kg.ha ${ }^{-1}$ a } & \\
\hline $\mathrm{RW}, \mathrm{m} 0.25$ & -- & -- & -- & $242.3 a$ & $173.0 \mathrm{c}$ \\
\hline 0.50 & $431.0 \mathrm{a}$ & $142.8 \mathrm{a}$ & $222.5 b$ & $241.1 \mathrm{a}$ & $290.5 b$ \\
\hline 0.76 & $380.0 \mathrm{a}$ & $126.6 \mathrm{a}$ & $350.2 \mathrm{a}$ & $279.2 \mathrm{a}$ & $354.1 \mathrm{a}$ \\
\hline PS, m 0.15 & $403.3 \mathrm{a}$ & $132.9 \mathrm{a}$ & $302.3 a$ & $251.2 \mathrm{a}$ & $272.3 \mathrm{a}$ \\
\hline 0.10 & $424.1 \mathrm{a}$ & $113.1 \mathrm{a}$ & $312.8 \mathrm{a}$ & $257.2 \mathrm{a}$ & $272.8 \mathrm{a}$ \\
\hline 0.075 & $389.0 \mathrm{a}$ & $158.0 \mathrm{a}$ & $243.8 b$ & -- & -- \\
\hline \multicolumn{6}{|l|}{$\mathrm{RW} \times \mathrm{PS}$} \\
\hline $0.25 \times 0.150$ & -- & -- & -- & $210.4 \mathrm{a}$ & $140.4 \mathrm{c}$ \\
\hline $0.25 \times 0.100$ & -- & -- & -- & $274.2 \mathrm{a}$ & $205.6 \mathrm{c}$ \\
\hline $0.25 \times 0.075$ & -- & -- & -- & -- & -- \\
\hline $0.50 \times 0.150$ & $407.9 a$ & $159.9 \mathrm{a}$ & $235.2 \mathrm{bc}$ & $237.6 a$ & $296.7 b$ \\
\hline $0.50 \times 0.100$ & $484.1 \mathrm{a}$ & $132.7 \mathrm{a}$ & $255.7 \mathrm{~b}$ & $244.7 \mathrm{a}$ & $284.3 b$ \\
\hline $0.50 \times 0.075$ & $401.0 \mathrm{a}$ & $135.7 \mathrm{a}$ & $176.6 c$ & -- & -- \\
\hline $0.76 \times 0.150$ & $398.8 \mathrm{a}$ & $105.9 \mathrm{a}$ & $369.5 a$ & $305.7 a$ & $379.8 \mathrm{a}$ \\
\hline $0.76 \times 0.100$ & $364.1 \mathrm{a}$ & $93.5 \mathrm{a}$ & $369.9 a$ & $252.7 \mathrm{a}$ & $328.4 \mathrm{ab}$ \\
\hline $0.76 \times 0.075$ & $377.1 \mathrm{a}$ & $180.4 \mathrm{a}$ & $311.1 \mathrm{a}$ & -- & -- \\
\hline \multicolumn{2}{|l|}{ Significance } & 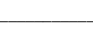 & $-\mathrm{P}>\mathrm{F}-$ & & \\
\hline RW & 0.2973 & 0.4333 & 0.0126 & 0.5691 & $<.0001$ \\
\hline PS & 0.7420 & 0.1485 & 0.0095 & 0.9199 & 0.9708 \\
\hline $\mathrm{RW} \times \mathrm{PS}$ & 0.4423 & 0.0848 & 0.8095 & 0.3786 & 0.0144 \\
\hline
\end{tabular}

a. Means of effects for the same year followed by the same letter are not significantly different, $\mathrm{P}<0.05$, according to the Tukey significant difference test. 
$\mathrm{kg} \cdot \mathrm{ha}^{-1}$ in 1999 in response to $>400 \mathrm{~mm}$ rain plus soil water for a total ET of 460 $\mathrm{mm}$, but the $135 \mathrm{~kg} \cdot \mathrm{ha}^{-1}$ mean yield low in 2000 followed seasonal rain totaling $139 \mathrm{~mm}$ and $70 \mathrm{~mm}$ soil water use that limited ET to a total of $210 \mathrm{~mm}$ (data not shown). The effects of row width and plant spacing on cotton lint yields were neutralized during these unusually wet or dry growing seasons. Measured lint yield for the conventional $0.76 \mathrm{~m}$ row spacing ranged from $15 \%$ to $120 \%$ larger than yields of the narrow, $0.50 \mathrm{~m}$, row spacing that were significantly different during the 2001 and 2004 growing seasons. The 2004 mean $173 \mathrm{~kg} \cdot \mathrm{ha}^{-1}$ yield for the ultra-narrow $0.25 \mathrm{~m}$ row spacing was about $50 \%$ of the lint yield for $0.76 \mathrm{~m}$ row spacing under dryland conditions; thus, differing from observations under irrigated or rain fed production [11] [12] [33]. By contrast, plant spacing produced no significant differences except for depressing the yield to $244 \mathrm{~kg} \cdot \mathrm{ha}^{-1}$ compared with the average $307 \mathrm{~kg} \cdot \mathrm{ha}^{-1}$ for the $0.10 \mathrm{~m}$ and $0.15 \mathrm{~m}$ plant spacing. Consistent with observed row spacing yield response, our modeled yield for the $0.38 \mathrm{~m}$ row spacing was $\sim 50 \%$ of the $582 \mathrm{~kg} \cdot \mathrm{ha}^{-1}$ yield calculated for the, $0.76 \mathrm{~m}$, conventional row spacing and did not vary significantly with plant spacing (Table 2). Model calculated dryland yields for $0.76 \mathrm{~m}$ rows, plotted in Figure 3 with increasing observation exceedance probability, were consistently greater than the corresponding yields for $0.38 \mathrm{~m}$ rows. In fact, approximately $80 \%$ of those yields from $0.76 \mathrm{~m}$ row spacing exceeded the greatest yield of the $0.38 \mathrm{~m}$ row spacing although the modeled yields less than $300 \mathrm{~kg} \cdot \mathrm{ha}^{-1}$ would be underestimated by as much as $50 \mathrm{~kg} \cdot \mathrm{ha}^{-1}$. The modeled yield results also provide no compelling evidence that plant spacing influenced the lint yields under these dryland conditions as measured under dryland and irrigated conditions [10]. That is, the data show that row spacing and not plant spacing influenced lint yield.

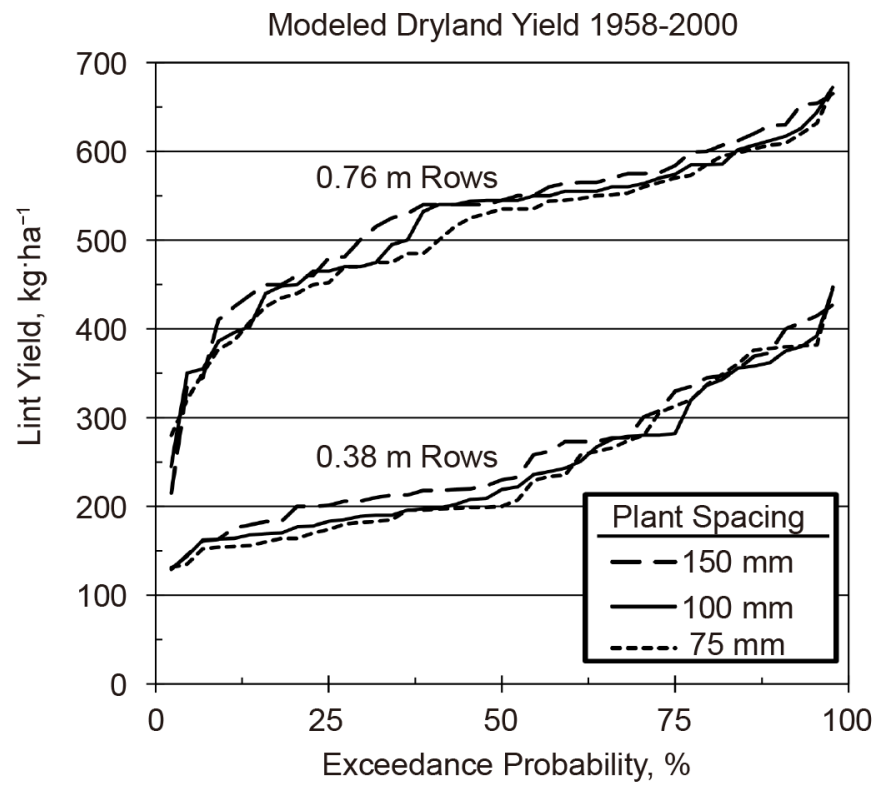

Figure 3. Exceedance probability for simulated lint yields for cotton grown with 0.38 and $0.76 \mathrm{~m}$ row spacing and in-row plant spacing intervals of $0.150,0.100$, and $0.075 \mathrm{~m}$. 
Lint quality can be revealing of environmental stresses imposed on the crop and the effect of management practices to offset them. For example, [34] observed that uniformly irrigated cotton lint quality factors and yield were generally unaffected by row spacing. Cotton fibers are formed in two phases that begin with rapid cell elongation during the first three weeks after bloom that establishes fiber length followed by fiber wall thickening as cellulose deposition continues through maturation about 30 days later. Any environmental stress caused by, for example, nutrient or water deficiency typically results in shortened or improperly matured fine or overly thickened fibers.

Our measured primary fiber quality factors of length and micronaire in response to treatment row and plant spacing are listed in Table 4 by year with the level of significance, but no corroborating model fiber quality results were possible because GOSSYM does not determine those properties [35] [36]. Fiber length exceeded the grade minimum $20.6 \mathrm{~mm}$, averaging $21.5 \mathrm{~mm}$ across the

Table 4. Fiber length and micronaire for each study year in response to row width (RW) and plant spacing (PS) treatments with the corresponding ANOVA significance levels.

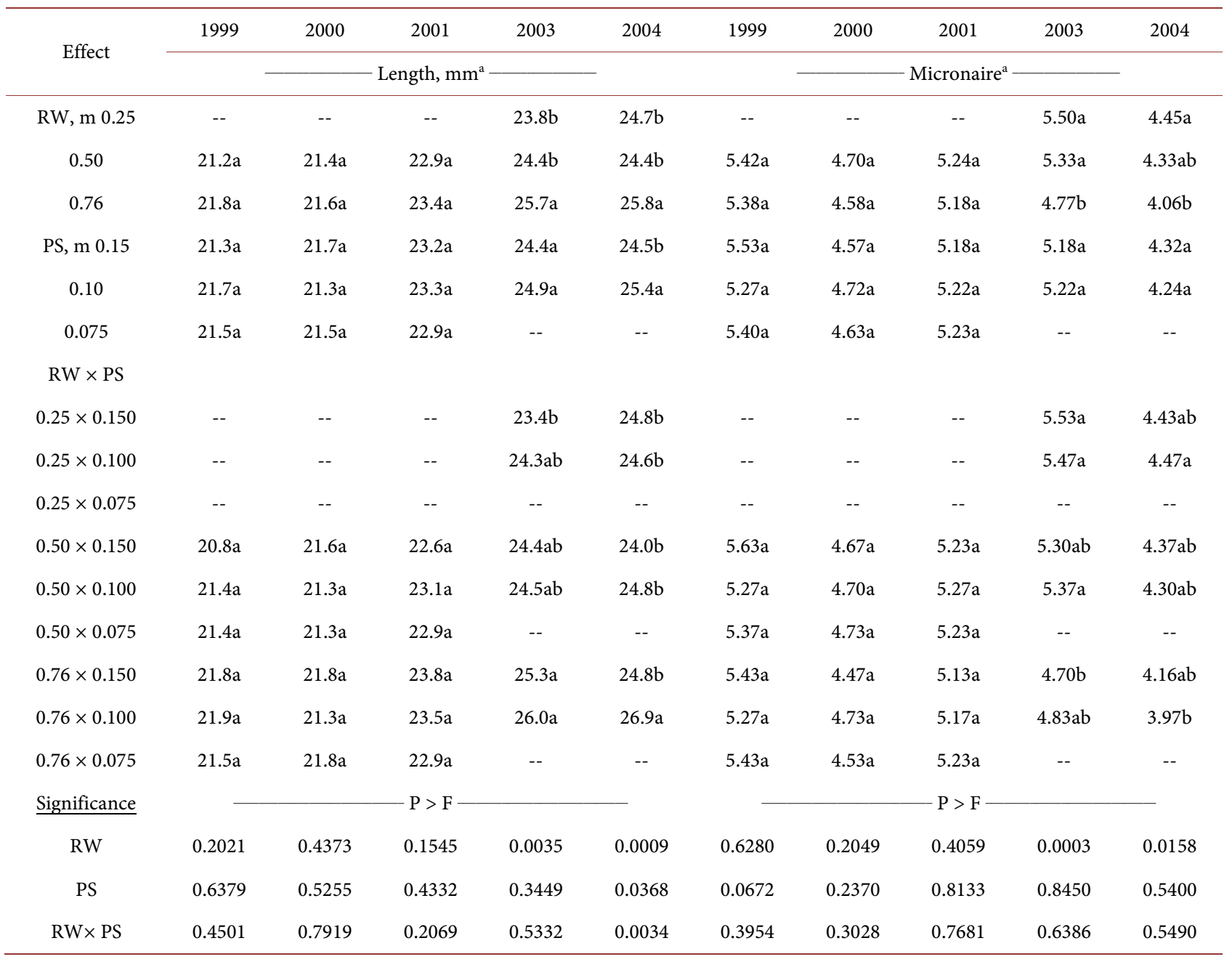

a. Means of effects for the same year followed by the same letter are not significantly different, $\mathrm{P}<0.05$, according to the Tukey significant difference test. 
combined row width and plant spacing treatments for both 1999 and 2000. The short fiber for 2000 was not surprising because during the July-September lint growth and maturation only $25 \mathrm{~mm}$ of precipitation was received during three events in July. For this period in 1999 rain exceeded $200 \mathrm{~mm}$ and would have been ample for lint growth, but the above average precipitation likely promoted use of soil nutrients including $\mathrm{N}$ vegetative growth in competition with nutrient demand for lint formation [36]. Precipitation during 2001 of $180 \mathrm{~mm}$ totaled less than almost $90 \%$ of the long-term May-September growing season precipitation and probably resulted in fiber length averaging $23.2 \mathrm{~mm}$ that was likewise unaffected by row or plant spacing treatments. Somewhat limited but better distributed precipitation in combination with available soil water resulted in significantly greater measured lint length for cotton grown in conventional $0.76 \mathrm{~m}$ wide rows compared with narrow or ultra-narrow row widths during 2003 and 2004. Although plant spacing resulted in no fiber length differences in 2003, lint length was greater with the $0.10 \mathrm{~m}$ plant spacing in 2004 . The measured micronaire, as observed for fiber length, did not differ significantly among any row or plant spacing treatments during 1999-2001. In fact, fiber micronaire did not vary with plant spacing treatment during any year of the study. Favorable fiber micronaire values for the 0.76 conventional row spacing were significantly better than those of the narrow or ultra-narrow row spacing as was observed for fiber length. The lint quality data show that the growing conditions with the conventional $0.76 \mathrm{~m}$ row width improved fiber length and micronaire during two of the five growing seasons evaluated. The $0.15-0.075 \mathrm{~m}$ plant spacing treatments also did not affect fiber quality with the exception of length in 2004 .

Length, micronaire, and other factors are combined to determine the lint price premium that we present in Table 5 as an integrated indicator of the fiber quality. No direct comparisons between years may be made because premium discounts were year specific, but lower price discounts after 2001 may reflect favorable June rain that supported fiber lengthening. No significant premium differences were identified during any year between the 0.50 and $0.76 \mathrm{~m}$ row spacing except in 2003 when planting was delayed until mid-June followed by a dry, $\sim 7 \mathrm{~mm}$ rain, July. The conventional row spacing premium discount was significantly less than for the ultra-narrow, $0.25 \mathrm{~m}$, rows during both 2003 in 2004. These data show that the ultra-narrow and narrow row spacing tended to have more heavily discounted price premiums than with conventional row spacing. Plant spacing resulted in no significant differences in price premiums during all five growing seasons from 1999 to 2004 because of negligible effects on lint quality factors.

\section{Summary and Conclusions}

We hypothesized that the limited early set cotton crop produced with offsetting higher populations could achieve desirable yields despite growing seasons that are often considered by many risk-averse producers of southwestern Kansas and 
Table 5. Mean annual price premium, $\$ / 45 \mathrm{~kg}$, in response to $0.25-0.75 \mathrm{~m}$ row width (RW) and 0.075 - $0.150 \mathrm{~m}$ plant spacing (PS) with the corresponding ANOVA significance levels.

\begin{tabular}{|c|c|c|c|c|c|}
\hline \multirow{2}{*}{ Effect } & 1999 & 2000 & 2001 & 2003 & 2004 \\
\hline & \multicolumn{5}{|c|}{ - Lint Price Premium, \$ per $45 \mathrm{~kg}^{\mathrm{a}}$} \\
\hline RW, m 0.25 & -- & -- & -- & $-7.62 b$ & $-4.57 \mathrm{~b}$ \\
\hline 0.50 & $-14.79 \mathrm{a}$ & $-13.02 \mathrm{a}$ & $-14.87 \mathrm{a}$ & $-6.30 \mathrm{~b}$ & $-3.83 \mathrm{ab}$ \\
\hline 0.76 & $-14.76 \mathrm{a}$ & $-12.86 \mathrm{a}$ & $-12.88 \mathrm{a}$ & $-2.94 \mathrm{a}$ & $-3.36 \mathrm{a}$ \\
\hline PS, m 0.15 & $-14.89 \mathrm{a}$ & $-12.78 \mathrm{a}$ & $-13.09 \mathrm{a}$ & $-5.88 \mathrm{a}$ & $-4.23 \mathrm{a}$ \\
\hline 0.10 & $-14.08 \mathrm{a}$ & $-12.96 \mathrm{a}$ & $-14.06 \mathrm{a}$ & $-5.36 \mathrm{a}$ & $-3.61 \mathrm{a}$ \\
\hline 0.075 & $-15.36 \mathrm{a}$ & $-13.08 \mathrm{a}$ & $-14.48 \mathrm{a}$ & -- & -- \\
\hline \multicolumn{6}{|l|}{$\mathrm{RW} \times \mathrm{PS}$} \\
\hline $0.25 \times 0.150$ & -- & -- & -- & $-8.17 b$ & $-4.97 \mathrm{a}$ \\
\hline $0.25 \times 0.100$ & -- & -- & -- & $-7.07 \mathrm{~b}$ & $-4.17 \mathrm{a}$ \\
\hline $0.25 \times 0.075$ & -- & -- & -- & -- & -- \\
\hline $0.50 \times 0.150$ & $-15.32 \mathrm{a}$ & $-12.97 \mathrm{a}$ & $-14.82 \mathrm{a}$ & $-5.75 a b$ & $-4.10 \mathrm{a}$ \\
\hline $0.50 \times 0.100$ & $-13.63 \mathrm{a}$ & $-13.07 \mathrm{a}$ & $-14.83 \mathrm{a}$ & $-6.85 a b$ & $-3.57 \mathrm{a}$ \\
\hline $0.50 \times 0.075$ & $-15.42 \mathrm{a}$ & $-13.02 \mathrm{a}$ & $-14.97 \mathrm{a}$ & -- & -- \\
\hline $0.76 \times 0.150$ & $-14.47 \mathrm{a}$ & $-12.58 \mathrm{a}$ & $-11.37 \mathrm{a}$ & $-3.72 \mathrm{ab}$ & $-3.61 \mathrm{a}$ \\
\hline $0.76 \times 0.100$ & $-14.52 \mathrm{a}$ & $-12.85 \mathrm{a}$ & $-13.28 \mathrm{a}$ & $-2.17 \mathrm{a}$ & $-3.10 \mathrm{a}$ \\
\hline $0.76 \times 0.075$ & $-15.30 \mathrm{a}$ & $-13.15 \mathrm{a}$ & $-13.98 \mathrm{a}$ & -- & -- \\
\hline \multicolumn{2}{|l|}{ Significance } & 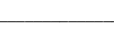 & $-\mathrm{P}>\mathrm{F}-$ & 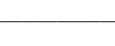 & \\
\hline RW & 0.9682 & 0.4599 & 0.2057 & 0.0106 & 0.0474 \\
\hline PS & 0.2853 & 0.3810 & 0.5834 & 0.6529 & 0.3205 \\
\hline $\mathrm{RW} \times \mathrm{PS}$ & 0.5426 & 0.4868 & 0.6366 & 0.5103 & 0.9158 \\
\hline
\end{tabular}

a. Means of effects for the same year followed by the same letter are not significantly different, $\mathrm{P}<0.05$, according to the Tukey significant difference test.

the Texas Panhandle as too limited in duration and energy. The plant height of cotton grown using narrow, $0.50 \mathrm{~m}$, and ultra-narrow, $0.25 \mathrm{~m}$, row spacing decreased from $15 \%$ to $30 \%$ compared with conventional $0.76 \mathrm{~m}$ row spacing during predominately drier growing seasons with significant differences due to plant spacing approaching $10 \%$ during the first three years. Lint yield and plant boll number for generally drier growing conditions were increased with wider row spacing by up to $50 \%$, although differences were not always significant. We used long-term weather records with GOSSYM in simulating cotton growth and yield to expand the basis of comparison for cotton response to row and plant spacing. Narrow rows consistently decreased modeled plant height, boll number, leaf area index, and active fruit initiation between bloom and cutout; however, only the modeled boll number differed with in row plant spacing. The resulting simulated yield for $0.38 \mathrm{~m}$ rows decreased by approximately $50 \%$ compared with 
the $582 \mathrm{~kg} \cdot \mathrm{ha}^{-1}$ yield for conventional row spacing. Field plot fiber quality was generally unaffected by the planting geometry except for degradation with ultra-narrow row spacing that also depressed the corresponding price premium.

We conclude that using narrow rows or frequent plant spacing did not improve net lint yield or fiber quality of dryland cotton. Concentrating on early set cotton boll production by adapting planting geometry to increase plant population and, consequently, cotton yield is not recommended under dryland conditions to overcome a thermally limited growing season.

\section{Declarations}

Mention of trade names or commercial products in this publication is solely for the purpose of providing specific information and does not imply recommendation or endorsement by the U.S. Department of Agriculture. The USDA is an equal opportunity provider and employer.

\section{References}

[1] Follett, R.F., Stewart, C.E., Pruessner, E.G. and Kimble, J.M. (2012) Effects of Climate Change on Soil Carbon and Nitrogen Storage in the US Great Plains. Journal of Soil and Water Conservation, 67, 331-342. https://doi.org/10.2489/jswc.67.5.331

[2] Stewart, B.A. (2003) Aquifers, Ogallala. In: Stewart, B.A. and Howell, T.A., Eds., Encyclopedia of Water Science, Marcel Dekker, Inc., New York, 43-44.

[3] McGuire, V.L. (2017) Water-Level and Recoverable Water in Storage Changes, High Plains Aquifer, Predevelopment to 2015 and 2013-15. U.S. Geological Survey Scientific Investigations Report 2017-5040, U.S. Geological Survey, Reston, VA, 14 p. https://doi.org/10.3133/sir20175040

[4] Wanjura, D.F. and Newton, O.H. (1981) Modeling Cotton Lint Development. Transactions of the American Society of Agricultural Engineers, 24, 496-499. https://doi.org/10.13031/2013.34283

[5] Bynum, J.B. and Cothren, J.T. (2008) Indicators of Last Effective Boll Population and Harvest Aide Timing in Cotton. Agronomy Journal, 100, 1106-1111. https://doi.org/10.2134/agronj2007.0134

[6] Gowda, P.H., Baumhardt, R.L., Esparza, A.M., Marek, T.H. and Howell, T.A. (2007) Suitability of Cotton as an Alternative Crop in the Ogallala Aquifer Region. Agronomy Journal, 99, 1397-1403. https://doi.org/10.2134/agronj2006.0275

[7] Stewart, B.A. and Peterson, G.A. (2015) Managing Green Water in Dryland Agriculture. Agronomy Journal, 107, 1544-1553. https://doi.org/10.2134/agronj14.0038

[8] Bilbro, J.D. (1981) Spatial Responses of Contrasting Cotton Cultivars Grown under Semiarid Conditions. Agronomy Journal, 73, 271-277. https://doi.org/10.2134/agronj1981.00021962007300020007x

[9] Bednarz, C.W., Bridges, D.C. and Brown, S.M. (2000) Analysis of Cotton Yield Stability across Population Densities. Agronomy Journal, 92, 128-135. https://doi.org/10.2134/agronj2000.921128x

[10] Kimura, E., Ramirez, J.H., Adams, C., Thapa, S. and DeLaune P. (2017) Cotton Growth, Lint Yield, and Fiber Quality as Influenced by Seeding Rates under Dryland and Irrigation in the Rolling Plains of Texas. Proceedings Beltwide Cotton 
Production Conference, Technical Paper, Dallas, TX, 4-6 January 2017, 92-95.

[11] Gerik, T.J., Lemon, R.G., Faver, K.L., Hoelewyn, T.A. and Jungman. M. (1998) Performance of Ultra-Narrow Row Cotton in Central Texas. Proceedings Beltwide Cotton Production Conference, Technical Paper, San Diego, CA, 5-9 January 1998, 1406-1409.

[12] Gwathmey, C.O., Steckel, L.E., Larson, J.A. and Mooney, D.F. (2011) Lower Limits of Cotton Seeding Rates in Alternative Row Widths and Patterns. Agronomy Journal, 103, 584-592. https://doi.org/10.2134/agronj2010.0333

[13] Boquet, D.J. (2005) Cotton in Ultra-Narrow Row Spacing: Plant Density and Nitrogen Fertilizer Rates. Agronomy Journal, 97, 279-287. https://doi.org/10.2134/agronj2005.0279

[14] Gwathmey, C.O. and Clement, J.D. (2010) Alteration of Cotton Source-Sink Relations with Plant Population Density and Mepiquat Chloride. Field Crops Research, 116, 101-107. https://doi.org/10.1016/j.fcr.2009.11.019

[15] Vories, E.D. and Glover, R.E. (2006) Comparison of Growth and Yield Components of Conventional and Ultra-Narrow Row Cotton. Journal of Cotton Science, 10, 235-243.

[16] Balkcom, K.S., Price, A.J., Van Santen, E., Delaney, D.P., Boykin, D.L., Arriaga, F.J., Bergtold, J.S., Kornecki, T.S. and Raper, R.L. (2010) Row Spacing, Tillage System, and Herbicide Technology Affects Cotton Plant Growth and Yield. Field Crops Research, 117, 219-225. https://doi.org/10.1016/j.fcr.2010.03.003

[17] Unger, P.W. and Pringle, F.B. (1981) Pullman Soils: Distribution Importance, Variability, and Management. Texas Agric. Exp. Stn. Bulletin, B-1372, College Station.

[18] Schwartz, R.C., Baumhardt, R.L., Scanlon, B.R., Bell, J.M., Davis, R.G., Ibragimov, N., Jones, O.R. and Reedy, R.C. (2015) Long-Term Changes in Soil Organic Carbon and Nitrogen under Semiarid Tillage and Cropping Practices. Soil Science Society of America Journal, 79, 1771-1781. https://doi.org/10.2136/sssaj2015.06.0241

[19] Baumhardt, R.L., Schwartz, R.C., Jones, O.R., Scanlon, B.R., Reedy, R.C. and Marek, G.W. (2017) Long-Term Conventional and No-Tillage Effects on Field Hydrology and Yields of a Dryland Crop Rotation. Soil Science Society America Journal, 81, 200-209. https://doi.org/10.2136/sssaj2016.08.0255

[20] Morrow, M.R. and Krieg, D.R. (1990) Cotton Management Strategies for a Short Growing Season Environment: Water-Nitrogen Considerations. Agronomy Journal, 82, 52-56. https://doi.org/10.2134/agronj1990.00021962008200010011x

[21] Johnson, W.C., Skidmore, E.L., Tucker, B.B. and Unger, P.W. (1983) Soil Conservation: Central Great Plains Winter Wheat and Range Region. In: Dregne, H.E. and Willis, W.O., Eds., Dryland Agriculture Agronomy Monograph No. 23, American Society Agronomy, Madison, 197-217.

[22] Eck, H.V. (1969) Restoring Productivity on Pullman Silty Clay Loam Subsoil under Limited Moisture. Soil Science Society of America Journal, 33, 578-581. https://doi.org/10.2136/sssaj1969.03615995003300040028x

[23] Eck, H.V. (1988) Winter Wheat Response to Nitrogen and Irrigation. Agronomy Journal, 80, 902-908. https://doi.org/10.2134/agronj1988.00021962008000060013x

[24] Jones, O.R., Hauser, V.L. and Popham, T.W. (1994) No-Tillage Effects on Infiltration, Runoff and Water Conservation on Dryland. Transactions of the American Society of Agricultural Engineers, 37, 473-479. https://doi.org/10.13031/2013.28099

[25] Milliken, G.A. and Johnson, D.E. (2009) Analysis of Messy Data Vol. 1 Designed 
Experiments. 2nd Edition, CRC Press Taylor \& Francis Group, Boca Raton.

[26] SAS Inst. Inc. (2004) SAS Online Doc 9.1.3. SAS Inst. Inc., Cary.

[27] Baker, D.N., Lambert, J.R. and McKinion, J.M. (1983) GOSSYM: A Simulator of Cotton Crop Growth and Yield. South Carolina Agric. Exp. Stn. Bull. 1089, Clemson Univ., Clemson.

[28] Reddy, K.R., Kakani, V.G., McKinion, J.M. and Baker, D.N. (2002) Applications of a Cotton Simulation Model, GOSSYM, for Crop Management, Economic and Policy Decisions. In: Ahuja, L.R., et al., Eds., Agricultural System Models in Field Research and Technology Transfer, CRC Press, Boca Raton, 33-73.

https://doi.org/10.1201/9781420032413.ch3

[29] Staggenborg, S.A., Lascano, R.J. and Krieg, D.R. (1996) Determining Cotton Water Use in a Semiarid Climate with the GOSSYM Cotton Simulation Model. Agronomy Journal, 88, 740-745. https://doi.org/10.2134/agronj1996.00021962008800050010x

[30] Baumhardt, R.L., Lascano, R.J. and Krieg, D.R. (1995) The Physical and Hydraulic Properties of a Pullman and Amarillo Soil on the Texas South Plains. Tech. Rep. 95-1, Texas Agric. Exp. Stn., Lubbock.

[31] Baumhardt, R.L., Mauget, S.A., Gowda, P.H. and Brauer, D.K. (2014) Modeling Cotton Lint Yield Response to Irrigation Management as Influenced by El Niño-Southern Oscillation. Agronomy Journal, 106, 1559-1568. https://doi.org/10.2134/agronj13.0451

[32] Jost, P.H. and Cothren, J.T. (2001) Phenotypic Alterations and Crop Maturity Differences in Ultra-Narrow Row and Conventionally Spaced Cotton. Crop Science, 41, 1150-1159. https://doi.org/10.2135/cropsci2001.4141150x

[33] Brodrick, R., Bange, M.P., Milroy, S.P. and Hammer, G.L. (2010) Yield and Maturity of Ultra-Narrow Row Cotton in High Input Production Systems. Agronomy Journal, 102, 843-848. https://doi.org/10.2134/agronj2009.0473

[34] Clawson, E.L., Cothren, J.T. and Blouin, D.C. (2006) Nitrogen Fertilization and Yield of Cotton in Ultra-Narrow and Conventional Row Spacing. Agronomy Journal, 98, 72-79. https://doi.org/10.2134/agronj2005.0033

[35] Reddy, V.R., Reddy, K.R., Sailaja, K., Richardson, A.G., Kakani, V.G. and Zhao, D. (2003) Cotton Modeling: Advances and Gaps in Our Ability to Assess Climate Change, Crop Management, Economic and Environmental Policy Decisions. Proceedings World Cotton Research Conference, Technical Paper, Cape Town, 9-13 March 2003, 882-895.

[36] Lokhande, S.B. and Reddy, K.R. (2015) Cotton Reproductive and Fiber Quality Responses to Nitrogen Nutrition. International Journal of Plant Production, 9, 191-210. 